\title{
RESEARCH ON POSITIVITY AND PSYCHOLOGICAL CAPITAL AT SCIENCE AND STUDY INSTITUTIONS IN THE USA
}

\author{
Aistė DIRŽYTÉ \\ Associate Professor, PhD, Institute of Psychology, \\ Mykolas Romeris University, Ateities str. 20, Vilnius, Lithuania \\ Phone number: +37061459911. E-mail: aidir@mruni.eu \\ doi:10.13165/IE-13-7-3-09
}

\begin{abstract}
The article analyses current research trends on psychological capital (PsyCap) in science and study institutions in the United States of America. The model of PsyCap, which is created by F. Luthans and colleagues, is introduced. The paper gives some evidence on how PsyCap components (self-efficacy, hope, optimism, psychological resilience) have been determined to meet the criteria of being state-like/open to development, being theory/research-based, having valid measurement, and having performance impact. Luthans and colleagues utility analysis of developing psychological capital has yielded a very high return on development. The paper discusses how the level of psychological capital could be linked to individual or organisational economic efficiency and what additional studies are required.
\end{abstract}

JEL classification: I0.

Keywords: psychological capital, job satisfaction, positive organisational behaviour.

Reikšminiai žodžiai: psichologinis kapitalas, pasitenkinimas darbu, teigiama organizacinè elgsena.

\section{Introduction}

The recent wave of negativity stemming from corporate and geopolitical problems draws attention to the need for more positivity in the world and the result has been a re-emphasis in the use of a positive lens for organisational behaviour theory, research, and practice at science and study institutions in the USA. Although the importance of positivity has gained focus through the years, only recently it has been proposed as a new lens to focus the study on organisational behaviour (Cameron, Dutton, \& Quinn, 2003; Luthans, 2002a, 2002b; Luthans \& Youssef, 2007; Luthans, Youssef, \& Avolio, 2007; Nelson \& Cooper, 2007; Roberts, 2006; Turner, Barling, \& Zacharatos, 2002; Wright, 2003), and these new trends are discussed in this article. 


\section{Research on Positivity at the Workplace}

Right around the turn of the last century, the field of psychology began to place greater importance on investigation as to what was right with people and what contributed to human flourishing and growth potential (Seligman \& Csikszentmihalyi, 2000; Sheldon \& King, 2001; Snyder \& Lopez, 2002). Drawn from the recent positive psychology movement (Peterson, 2006; Peterson \& Seligman, 2004; Seligman \& Csikszentmihalyi, 2000; Snyder \& Lopez, 2002), the positive focus extended to the workplace, by focusing on both the value of micro-oriented positivity in individuals as well as macro-oriented positivity in organisations (Luthans, 2002a, 2002b; Luthans, Youssef, \& Avolio, 2007; Nelson \& Cooper, 2007; Wright, 2003; Cameron \& Caza, 2004; Cameron, Dutton, \& Quinn, 2003; Roberts, 2006; Spreitzer \& Sonenshein, 2004).

Positive organisational behaviour was for the first time defined as "the study and application of positively oriented human resource strengths and psychological capacities that can be measured, developed, and effectively managed for performance improvement in today's workplace" (Luthans, 2002). Positive psychological resources, such as hope or resilience, once considered to be "a quality of gifted individuals" (Garmezy, 1974), now has obtained empirical support that they can be developed (Masten \& Reed, 2002; Snyder, 2000), as well as other capacities commonly recognised in the field of organisational behaviour, such as efficacy (Bandura, 1997; Stajkovic \& Luthans, 1998) and optimism (Seligman, 1998). Moreover, a specific construct of psychological capital was introduced (Luthans, 2007).

\section{Fred Luthans, author of PsyCap model, distinguished professor at the University of Nebraska}

The author of psychological capital (PsyCap) construct is Fred Luthans (born in 1939). He is University and George Holmes Distinguished Professor of Management at the University of Nebraska, U.S.A. As the former President of the Academy of Management, he received the Academy's Distinguished Educator Award. Currently F. Luthans is an editor of the Journal of World Business, Organizational Dynamics, and Journal of Leadership and Organization Studies. He is the author of several well-known books and numerous research articles on positive organisational behaviour and psychological capital. His textbook Organizational Behavior is now in its 12th edition (McGraw Hills, 2012) and his latest book is Psychological Capital (Oxford University Press, 2007). His recent investigations have been focused on the theory construction, measurement, and performance impact of this positive approach.

\section{Psychological Capital Theory}

Psychological capital is conceptualised as an individual's positive psychological state of development characterised by: (1) having confidence (self-efficacy) to take on 
and put in the necessary effort to succeed at challenging tasks; (2) making a positive attribution (optimism) about succeeding now and in the future; (3) persevering towards goals and, when necessary, redirecting paths to goals (hope) in order to succeed; and (4) when beset by problems and adversity, sustaining and bouncing back and even beyond (resiliency) to attain success (Luthans, Youssef, et al., 2007, p. 3).

Psychological capital is seen as a resource that goes beyond human capital (experience, knowledge, skills and abilities) and social capital (relationships, networks). It deals with "who you are here and now", and "who you can become" in the proximal future if your psychological resources are developed and nurtured in the workplace (Luthans, Luthans, \& Luthans, 2004; Luthans \& Youssef, 2004). To date, surveys support that the four component resources load on the higher-order core construct of psychological capital and indicate convergent and discriminant validity with similar positive constructs, such as core self-evaluations and relevant personality traits, such as conscientiousness (Avey, Luthans, \& Jensen, 2009; Luthans, Avolio, Avey, \& Norman, 2007).

\section{Psychological Capital Measurement}

In terms of measurement, a valid and reliable PsyCap questionnaire has been developed (Luthans, Youssef et al., 2007) and empirically validated (Luthans, Avolio et al., 2007). The items used therein were originally drawn from published validated scales commonly used in positive psychology. These individual scales have also been used in previous studies in the workplace (e.g., Peterson \& Luthans, 2003, Luthans et al., 2005; Youssef \& Luthans, 2007). Six items in this questionnaire represent each of the four components that make up PsyCap. These items were adapted for the workplace from the following standard scales: (1) Hope (Snyder et al., 1996); (2) Resilience (Wagnild \& Young, 1993); (3) Optimism (Scheier \& Carver, 1985); and (4) Efficacy (Parker, 1998).

Therefore, PsyCap meets the criteria of valid measurement and openness to development, and a growing number of studies have clearly demonstrated that it has impact on the desired outcomes in the workplace. For example, in one major study PsyCap was shown to be positively related to employee satisfaction (Luthans, Avolio, et al., 2007). There is also increasing evidence that PsyCap is significantly related to desired employee behaviours (and negatively to undesired behaviours), attitudes (e.g., satisfaction and commitment), and performance (Luthans, Avolio et al., 2007). Research studies evidently demonstrate the impact that PsyCap may have on satisfaction and/or commitment (Larson \& Luthans, 2006; Luthans, Avolio et al., 2007; Luthans, Norman et al., 2008; Youssef \& Luthans, 2007) and absenteeism (Avey, Patera, \& West, 2006).

Several researches on the subject have already provided some evidence that the relative stability of PsyCap makes the return on investment in its development more sustainable in the workplace (Luthans, Avolio et al., 2007; Luthans, Avey \& Patera, 2008) (the emphasis on demonstrating objective work-related outcomes of PsyCap best fits Pfeffer's (1997) economic model of behaviour). 


\section{Recent Research on Psychological Capital in Science and Study Institutions in the USA}

Although PsyCap predominately focuses on positivity at the individual level, expanding research in the science and study institutions in the USA has also demonstrated positive relations between collective PsyCap and team performance (Clapp-Smith, Vogelgesang, \& Avey, 2009; Peterson \& Zhang, 2011; Walumbwa, Luthans, Avey, \& Oke, 2011). There are at present in excess of 45 published PsyCap papers, and the emergence of the first meta-analysis is further evidence of the growth of PsyCap research (Avey, Reichard, et al., 2011).

Some empirical research indicates that positive appraisals of life domains besides work (i.e., Relationship PsyCap and Health PsyCap) impact on employee's overall well-being (Luthans, Youssef, Sweetman, \& Harms, 2010; Luthans \& Harms, 2013). Furthermore, work-related positivity is viewed as antecedent not only of proximal work outcomes, but also for overall well-being over time (Avey, Luthans, Smith, \& Palmer, 2010). A recent meta-analysis has provided further evidence of significant, positive relationships between PsyCap and job satisfaction, organisational commitment, organisational citizenship behaviours and job performance and negative relationships with turnover intent, cynicism, job stress and deviance (Avey, Reichard, Luthans, \& Mhatre, 2011).

\section{Conclusions and Implications}

There is an expanding research across science and study institutions in the USA demonstrating the positive relationship between PsyCap and desired employee outcomes, and there is also conceptual and empirical evidence that PsyCap can be developed (Luthans, Avey, Avolio, Norman, \& Combs, 2006; Luthans, Youssef, \& Avolio, 2007; Luthans, Avey, \& Patera, 2008). Nonetheless, supplementary research is needed to test further whether PsyCap can be developed via the training model as well as to determine its impact on individual performance (Luthans, Avey et al., 2006; Luthans, Avey, \& Patera, 2008; Luthans, 2010).

\section{References}

1. Avery, D. R.; McKay, P. F.; Wilson, D. C. Engaging the aging workforce: The relationship between perceived age similarity, satisfaction with coworkers, and employee engagement // Journal of Applied Psychology. 2007, vol. 92(6), p. 1542-1556.

2. Avey, J. B.; Luthans, F.; Youssef, C. M. The Additive Value of Positive Psychological Capital in Predicting Work Attitudes and Behaviors // Journal of Management OnlineFirst. 2009, p. 1-23.

3. Avey, J. B., Patera, J. L., Wes, B. J. The Implications of Positive Psychological Capital on Employee Absenteeism // Journal of Leadership \& Organizational Studies. 2006, vol. 13(2), p. 42-60. 
4. Avey, J. B.; Reichard, R. J.; Luthans, F.; Mhatre, K. H. Meta-analysis of the Impact of Positive Psychological Capital on Employee Attitudes, Behaviors, and Performance // Articles Human Resource Development Quarterly. 2011, vol. 22(2), p. 127-152.

5. Avey, J. B.; Wernsing, T. S.; Luthans, F. Can Positive Employees Help Positive Organizational Change? Impact of Psychological Capital and Emotions on Relevant Attitudes and Behaviors // The Journal of Applied Behavioral Science. 2008, vol. 44(1), p. 48-70.

6. Avey, James B.; Tara S. Wernsing, and Ketan H. Mhatre. A Longitudinal Analysis of Positive Psychological Constructs and Emotions on Stress, Anxiety, and Well-Being. Journal of Leadership \& Organizational Studies, May 2011; vol. 18, 2: pp. 216-228.

7. Aydogdu, S.; Asikgil, B. An Empirical Study of the Relationship among Job Satisfaction, Organizational Commitment and Turnover Intention // International Review of Management and Marketing. 2011, vol. 1(3), p. 43-53.

8. Cole, K.; Daly, A.; Mak, A. Good of the Soul: The Relationship between work, wellbeing and Psychological Capital // The Journal of Socio-Economics. 2009, vol. 38, p. $464-474$.

9. Garg, P.; Rastogi, R. Effect of psychological wellbeing on organization commitment of employees // The IUP Journal of Organizational Behaviour. 2009, p. 1-11.

10. Kelloway, E. Kevin; Weigand, H.; Margaret C. McKee, and Hari Das. Positive Leadership and Employee Well-Being. Journal of Leadership \& Organizational Studies, February 2013; vol. 20, 1: pp. 107-117.

11. Larson, M.; Luthans, F. Potential Added Value of Psychological Capital in Predicting Work Attitudes // Journal of Leadership and Organizational Studies. 2006, vol. 13(1), p. 45-62.

12. Luthans, F. Psychological Capital: Implications for HRD, Retrospective Analysis, and Future Directions // Articles Human Resource Development Quarterly. 2012, vol. 23(1), p. 1-7.

13. Luthans, F.; Avey, J. B.; Avolio, B. J.; Norman, S. M., Combs, G. M. Psychological Capital Development: Toward a Micro - Intervention // Journal of Organizational Behaviour. 2006a, vol. 27, p. 387 - 393. Luthans, F., Avey, J. B., Avolio, B. J., Peterson, S. J. The Development and Resulting Performance Impact of Positive Psychological Capital // Articles Human Resource Development Quarterly. 2010, vol. 21(1), p. 4 -67.

14. Luthans, F.; Avey, J. B.; Clapp-Smith, R.; Li, W. More Evidence on the Value of Chinese workers' Psychological Capital: A Potentially Unlimited Competitive Resource // The International Journal of Human Resource Management. 2008c, vol. 19(5), p. 818 - 827.

15. Luthans, F.; Avey, J. B.; Patera, J. L. Experimental Analysis of a Web - Based Training Intervention to Develop Positive Psychological Capital // Academy of Management Learning \& Education. 2008b, vol. 7(2), p. 209-221.

16. Luthans, F.; Avolio, B. J.; Avey, J. B.; Norman, S. M. Positive Psychological Capital: Measurement and Relationship with Performance and Satisfaction // Personnel Psychology. 2007, vol. 60, p. 541-572.

17. Luthans, F.; Norman, S. M.; Avolio, B. J.; Avey, J. B. The Mediating Role of Psychological Capital in the Supportive Organizational Climate - Employee Performance relationship // Journal of Organizational Behavior. 2008a, vol. 29, p. 219-238. 
18. Luthans, F.; Vogelsesang, G. R.; Lester, P. B. Developing the Psychological Capital of Resilience // Human Resource Development Review. 2006b, vol. 5(1), p. 25-44.

19. Luthans, Fred. "Can Positive Employees Help Positive Organizational Change?"(with James Avey and Tara Wernsing), Journal of Applied Behavioral Science, Vol. 44, No. 1, 2008, pp. 48-70.

20. Luthans, Fred. Experimental Analysis of a Web-Based Intervention to Develop Positive Psychological Capital (with James Avey and Jaime Patera), Academy of Management Learning and Education, Vol. 7, No. 2, 2008, pp. 209-221.

21. Luthans, Fred. Impact of Positive Psychological Capital on Employee Well-Being over Time (with James Avey, Ronda Smith and Noel Palmer), Journal of Occupational Health Psychology, Vol. 15, 2010, pp. 17-28.

22. Luthans, Fred. Positive Organizational Behavior in the Workplace: The Impact of Hope, Optimism, and Resilience (with Carolyn Youssef), Journal of Management, 33, 2007, pp. 774-800.

23. Luthans, Fred. Positive Psychological Capital: Measurement and Relationship with Performance and Satisfaction (with Bruce Avolio, James Avey and Steven Norman), Personnel Psychology, Vol. 60, 2007, autumn, pp. 541-572.

24. Luthans, Fred. Psychological Capital: A Positive Resource for Combating Employee Stress and Turnover (with James Avey and Susan Jensen), Human Resource Management, Vol. 48, No. 5, 2009, pp. 677-693.

25. Luthans, Fred. Psychological Ownership: Theoretical Extensions, Measurement and Relation to Work Outcomes (with James Avey, Bruce Avolio and Craig Crossley), Journal of Organizational Behavior, Vol. 30, No. 2, 2009, pp. 173-191.

26. Luthans, Fred. Psychological Capital (with Carolyn Youssef and Bruce Avolio), Oxford, UK: Oxford University Press (2007, 246 pp.).

27. Luthans, Fred; Carolyn M. Youssef; David S. Sweetman, and Peter D. Harms. Meeting the Leadership Challenge of Employee Well-Being Through Relationship PsyCap and Health PsyCap. Journal of Leadership \& Organizational Studies, February 2013; vol. 20, 1: pp.118-133.

29. Norman, S. M., Avey, J. B., Nimnicht, J. L., Pigeon, N. G. The Interactive Effects of Psychological Capital and Organizational Identity on Employee Organizational Citizenship and Deviance Behaviors // Journal of Leadership \& Organizational Studies. 2010, vol. 17(4), p. 380-391.

30. Seligman, Martin. (2011). Flourish: A Visionary New Understanding of Happiness and Well-being. New York: Free Press.

31. Shahnawaz, M.G., Hassan Jafri, Md. Psychological Capital as Predictors of Organizational Commitment and Organizational Citizenship Behaviour // Journal of the Indian Academy of Applied Psychology. 2009, vol. 35, Special Issue, p. 78-84.

This research is funded by the European Social Fund under the Global Grant measure (No. VP1-3.1-ŠMM-07-K-03-032). 


\section{POZITYVUMO IR PSICHOLOGINIO KAPITALO TYRIMAI JAV MOKSLO INSTITUCIJOSE}

Santrauka. Straipsnyje analizuojami gyvenimo kokybès ir psichologinio kapitalo tyrimai, vykdomi Jungtinių Amerikos Valstijų mokslo ir studijų institucijose. Supažindinama su tendencija gyvenimo kokybę tirti atsižvelgiant ị sveikatos, santykių ir darbo veiksnių kokybès dimensijas. Analizuojamas šių veiksnių ryšys su psichologinio kapitalo konstruktu, kurị sukūrè Nebraskos universiteto mokslininkas prof. F. Luthans. Straipsnyje aptariama, kokie tyrimai atliekami, siekiant sukurti didelès praktinès vertès intervencinius mechanizmus.

Aistė DIRŽYTE் - Doctor of Social Sciences, Associate Professor at the Institute of Psychology, Mykolas Romeris University. Scientific research area: quality of life, subjective well-being.

Aistė DIRŽYTE் - Mykolo Romerio universiteto Psichologijos instituto docentè, socialinių mokslų daktarè. Mokslinių tyrimų sritis: gyvenimo kokybė, subjektyvi gerovè. 